\title{
Phytochemical Analysis, Antioxidant Properties and Brine Shrimp Lethality of Unripe Fruits of Solanum viarum
}

\author{
Welligton Luciano Braguini*, Natalia Valendolf Pires, Bruno Bianchin Alves \\ Department of Biological Sciences, Biochemistry Laboratory, Universidade Estadual do Centro Oeste. Guarapuava, Paraná, BRAZIL.
}

\begin{abstract}
Objective: The aim of the study was evaluate the tannin content, antioxidant activity and the lethality of unripe fruits extract of Solanum viarum Dunal (Solanaceae) against brine shrimps. Methods: The tested samples for tannins content were water, ethanol:water (1:3) and acetone:water (1:3) extract. The unripe fruits powder of $S$. viarum was used to extraction in a Soxhlet apparatus for 2 hr. Cytotoxicity was screened using Brine Shrimp Lethality Test and aqueous extract. Results: The results demonstrated that the yield of tannins for the acetone:water extraction was substantially higher than that typical yields obtained by ethanol:water or water extraction [31.10\% for Total Solids (\%), 14.99\% for Stiasny's Index (\%), 3.99\% for Condensed Tannins in the Extract (\%) and $1.09 \%$ for Condensed Tannins in the Unripe Fruits (\%). The antioxidant activity was $61.12 \pm 12.42$ $\%$ compared to ascorbic acid (100\%) and polyphenol concentration was $39.33 \pm 4.45 \mathrm{mg}$ of tannic acid/g of extract obtained from the tannic acid calibration curve $y=0.0128 x-0.0015\left(R^{2}=0.9988\right)$. Flavonoid concentration was $89.36 \pm 11.6 \mathrm{mg}$ of quercetin $/ \mathrm{g}$ of extract obtained by quercetin calibration curve $y=0.0153 x+0.0109, R^{2}=0.9827$. The results demonstrated that the positive control (potassium dichromate) hatching success was
\end{abstract}

significantly higher than the $S$. viarum extract $(P<0.05)$. $L_{50}$ was 66.01 $\mu \mathrm{g} / \mathrm{ml}$ for the water extract of unripe fruit of $S$. viarum and in accord to Clarkson's toxicity criterion, $\mathrm{LC}_{50}<100 \mu \mathrm{g} / \mathrm{mL}$ are considered highly toxic for aqueous extract. Conclusion: The unripe fruit extract of $S$. viarum demonstrated low percentage in phenolic content, but significant antioxidant activity and phenolic and flavonoid concentrations. S. viarum unripe fruits extract is toxic to Artemia salina.

Key words: Solanum viarum, Toxicity, Antioxidant, Flavonoid, Phenolic, $\mathrm{LC}_{50}$, Artemia salina.

\section{Correspondence}

Dr. Welligton Luciano Braguini, Simeão Varela de Sá Street, number 03, Guarapuava, Paraná, BRAZIL.

Phone: 55 (42) 3629-8136

Email: wbraguini@unicentro.br

DOI: 10.5530/jyp.2018.10.36

\section{INTRODUCTION}

Solanum viarum Dunal also known as "juá, joá-bravo" in Brazil and is a common plant in the Latin America. It is a toxic plant, and have medicinal properties. ${ }^{1}$ It can be found as an encroachment of pastures, along roadsides and crops, and is considered a problem for livestock farmers due to their toxicity around the world, principally in Brazil and USA. ${ }^{2}$

Because S. viarum is a plant full of thorns, including thorns in the leaves, it is not eaten by many animals. However, the cattle, using its tongue, reach the fruits of $S$. viarum, and in this way it is an excellent disseminator of seeds through feces. Others animals also spread the seeds through the feces. ${ }^{3}$ However, some cases reported in the literature demonstrated that the fruits are toxic to cattle and to other types of herds. ${ }^{4}$ Mentz et al. ${ }^{5}$ explained that the fruits of $S$. viarum when ingested by cattle produce intense and lethal tympani and the leaves exhibit narcotic properties.

Genus Solanum is rich in steroidal glycoalkaloids and solasodine is a nitrogen analogue of sapogenins found in this genus. This compound (C27 cholestane skeleton) can be converted in a key intermediate in the synthesis of steroidal drugs and it is potential moiety to be used in the production of steroidal hormones in pharmaceuticals. ${ }^{6}$ Glycoalkaloids are toxic for living organisms due to their anticholinesterase activities and rupture of cell membranes related to effects including teratogenicity, embryotoxicity and genotoxicity. ${ }^{7}$ Among the medicinal properties of species of genus Solanum is the use of roots as diuretic, they improve the functions of the liver and bladder and its plaster eliminates skin boils. ${ }^{8}$ Some glycoalkaloids are beneficial for the growth of plants and have medicinal effects on humans. They can protect against damage caused by insects and fungi, and may have anti-inflammatory ${ }^{9}$ and anticancer activity in humans. ${ }^{10}$ Biological investigations of glycoalkaloids of Solanum showed significant cytotoxicity against human cancer cell lines and skin tumours. ${ }^{11}$

Cipollini and Levey ${ }^{12}$ comment about the propensity for immature Solanum fruits to accumulate high levels of alkaloids (1-7\% dry mass) and that these levels may or may not drop during fruit maturation. Glycoalkaloids can be highly toxic to vertebrates; in some species, their concentration in ripe fruit (up to $7 \%$ of dry mass) should be high enough to cause lethal effects in a $1-2 \mathrm{~kg}$ vertebrate after consumption of $<10$ fruits (based on an estimate of a $100-1000 \mathrm{mg} / \mathrm{kg}$ lethal dose in clinical and case studies with domestic animals and humans. ${ }^{13,14}$

Considering the results from studies on S. viarum and the existence of few toxicological and biochemical studies regarding unripe fruits of S. viarum, we evaluated the tannins content, polyphenols and flavonoid concentration, antioxidant activity of unripe fruits of S. viarum and the toxicity of extract using brine shrimp lethality bioassay.

\section{MATERIALS AND METHODS}

\section{Plant extract}

The unripe fruits of Solanum viarum were collected in November 2016 in a farm in Pinhão District Municipality, Paraná State, Brazil. This area lies at Latitude $25^{\circ} 42^{\prime} 06.7^{\prime \prime}$ and Longitude 51 $38^{\prime} 20.6^{\prime \prime}$. The plant was authenticated by Dr. Eneida Martins Miskalo of Universidade Estadual do Centro Oeste - UNICENTRO, HUCO - Herbarium, Campus de Irati

This is an open access article distributed under the terms of the Creative Commons Attribution-NonCommercial-ShareAlike 4.0 License, which allows others to remix, tweak, and build upon the work non-commercially, as long as the author is credited and the new creations are licensed under the identical terms. 
Braguini et al.: Tannins Content and Toxicity of S. viarum in Brine Shrimp.

District, Paraná State, Brazil, and a voucher specimen (HUCO-7408) was prepared and deposited in the HUCO Herbarium. The unripe fruits was rinsed with deionized water and gently blotted with paper towel to remove the water, chopped into smaller bits and subsequently ovendried at $55^{\circ} \mathrm{C}$ for $72 \mathrm{hr}$ until constant weight was achieved, then ground into powder. Tannins were extracted from samples $(10 \mathrm{~g})$ with water, or ethanol:water (1:3) or acetone:water (1:3) using a Soxhlet apparatus for $2 \mathrm{hr}$.

\section{Determination of tannins}

The yield of the extract using water, ethanol:water and acetone:water was determined according to Guangcheng et al. ${ }^{15}$ By gravimetric method with adaptations. Stiasny's index [SI (\%)] was determined by Equation (1): $\mathrm{SI}(\%)=\left(\mathrm{m}_{1} / \mathrm{m}_{2}\right)^{*} 100$ (1) where $\mathrm{m}_{1}=$ dry mass of $50 \mathrm{ml}$ of extract after $24 \mathrm{hr}$ in the oven at $100{ }^{\circ} \mathrm{C}, \mathrm{m}_{2}=$ dry mass of formaldehyde and $\mathrm{HCl}$ reaction with tannins of $50 \mathrm{ml}$ of extract on the filter paper after 24 $\mathrm{hr}$ in the oven at $100{ }^{\circ} \mathrm{C}$. Solid total (\%) was obtained by Equation (2): $\left.\mathrm{ST}(\%)=\left[\left(\mathrm{M}_{1}-\mathrm{M}_{2}\right)\right] / \mathrm{M}_{1}\right]^{*} 100(2)$ where $\mathrm{M}_{1}=$ plant mass for extraction, $\mathrm{M}_{2}$ $=$ plant mass after extraction, drying in the oven at $100{ }^{\circ} \mathrm{C}$ for $24 \mathrm{hr}$ Condensed tannins content in the extract and Condensed tannins content in the unripe fruit were obtained by Equation (3) and (4): CTE $(\%)=[\mathrm{ST}(\%)$ * SI(\%)]/100 (3) and CTF(\%)=[CTE(\%)* ST(\%)]/100 (4).

\section{Polyphenol concentration}

Polyphenol concentration in the aqueous extract was evaluated by FolinCiocalteu method as reported by Singleton et al., ${ }^{16}$ The absorption was measured at $726 \mathrm{~nm}$ wavelength (Gehaka UV-340-G spectrophotometer) and the phenol concentration was expressed as tannic acid in $\mathrm{mg}^{-1} \mathrm{~g}^{-1}$ of dry weight extract by a linear equation based on the calibration curve for the tannic acid $y=0.0128 x-0.0015, R^{2}=0.9988$.

\section{Total flavonoid concentration}

A known volume of aqueous extract was placed in a glass tube. Distilled water was added to make $2 \mathrm{ml}$, and $0.15 \mathrm{ml} \mathrm{NaNO}$ (1:20) were added. $0.15 \mathrm{ml} \mathrm{AlCl}_{3}$ (1:10) were added 6 min later. After $6 \mathrm{~min}, 2 \mathrm{ml}$ of $4 \%$ $\mathrm{NaOH}$ was added and the total was made up to $5 \mathrm{ml}$ with distilled water. The solution was mixed well again and the absorbance was measured against a blank at $510 \mathrm{~nm}$ with a UV-visible spectrophotometer. ${ }^{17}$ Calibration curve for the quercetin was prepared $(0-0.2 \mathrm{mg} / \mathrm{ml})$ and the flavonoid content was calculated using the following linear equation based on the calibration curve for the quercetin: $y=0.0153 x+0.0109, R^{2}=0.9827$.

\section{Evaluation of Total Antioxidant Activity}

A $0.3 \mathrm{ml}$ aliquot of an aqueous diluted extract solution to $200 \mu \mathrm{g} / \mathrm{ml}$ was combined in a tube with $3 \mathrm{ml}$ of reagent solution $(0.6 \mathrm{M}$ sulfuric acid, $28 \mathrm{mM}$ sodium phosphate, and $4 \mathrm{mM}$ ammonium molybdate). The tubes containing the reaction solution were capped and incubated in a boiling water bath at $95^{\circ} \mathrm{C}$ for $90 \mathrm{~min}$. After cooling to room temperature, the absorbance of the solution was measured at $695 \mathrm{~nm}$ using a spectrophotometer. The reference substance used was ascorbic acid $200 \mu \mathrm{g} / \mathrm{mL}$. Ascorbic acid was considered as $100 \%$ activity antioxidant. ${ }^{18}$

\section{Artemia salina Hatching Assay}

This assay was evaluated as described by Otang et al. ${ }^{19}$ with little modifications. A density of ten A. salina cysts was stocked in each of tube containing $5 \mathrm{ml}$ of the prepared concentrations of the unripe fruits aqueous extract of $S$. viarum and positive control (potassium dichromate). The unripe fruits extract of $S$. viarum was dissolved in sea water to complete $10 \mathrm{ml}$ of total volume in concentration of $0.005,0.05,0.5,2.5$, $5.0,7.5$ and $10 \mathrm{mg} / \mathrm{ml}$. One $\mathrm{ml}$ of each dilution was added to tubes containing $4 \mathrm{ml}$ sea water and 10 cysts each to afford the final sample concentration. The final concentration was $1,10,100,500,1000,1500$ and $2000 \mu \mathrm{g} / \mathrm{ml}$. A positive control group was also prepared by dissolving the potassium dichromate in water at the same concentrations as the plant extract. The tubes were partly covered, incubated at $30{ }^{\circ} \mathrm{C}$ and under constant illumination for $72 \mathrm{hr}$ the percentage of hatchability was assessed by comparing the number of hatched nauplii with the total number of cysts stocked.

\section{Brine Shrimp Lethality Assay}

The brine shrimp lethality assay was performed following the reported procedure by Meyer et al. ${ }^{20}$ and McLaughlin et al. ${ }^{21}$. with some modifications. The growth medium was prepared with sea water in a small tank divided into two compartments. The shrimp eggs were added to the covered compartment. After $48 \mathrm{hr}$, the shrimps mature as nauplii (A. salina) and are ready for the assay. The final concentration tested of unripe fruit extract of $S$. viarum was $1,10,100,500,1000,1500$ and $2000 \mu \mathrm{g} / \mathrm{ml}$. A positive control group was also prepared by dissolving the potassium dichromate in water at the same concentrations as the plant extract. After $24 \mathrm{hr}$ incubation under light, the number of dead and survivor brine shrimps in each tube was counted. The percentage of mortality was calculated as Equation (5): Mortality $(\%)=[($ Total nauplii - Alive nauplii ${ }^{\star} 100 /$ Total nauplii] $(5)^{5}$

\section{Data Analysis}

Antioxidant activity, polyphenols and flavonoid concentration values were determined from the best-fit line obtained by regression analysis. The median lethal concentration $\left(\mathrm{LC}_{50}\right)$ and $95 \%$ confidence intervals of the test samples were calculated using the probity analysis method described by Finney, ${ }^{22}$ as the measure of toxicity of the plant extract. For statistical significance, the study was carried out in 5 experiments in triplicate. The differences between the groups were determined by Analysis of Variance (ANOVA) followed, when detected, by Tukey's multiple comparisons test. The analysis was done using GraphPad Prism ${ }^{\circledR}$ version 5.01 for Windows ${ }^{\oplus}$, Graph Pad Software ${ }^{\oplus}$, and San Diego, California, USA. The results were considered statistically significant when $P<0.05$.

\section{RESULTS}

Figure 1(a-d) represent the mean values of total solids content [TS (\%)], Stiasny's index [SI (\%)], condensed tannins content in the extract [CTE (\%)] and condensed tannins content in the unripe fruits [CTF (\%)]. The solvents water, ethanol:water (1:3) and acetone:water (1:3) were used to prepare unripe fruits extract of $S$. viarum using a Soxhlet apparatus for $2 \mathrm{hr}$ TS (\%) express the sum of tannic and non-tannic substances contained in the extracts. When the extraction was made with water, ethanol:water and acetone:water the TS (\%) value was $16.87 \pm 1.69 \%$, $13.35 \pm 2.50 \%$ and $31.10 \pm 0.32 \%$, respectively, and the comparison between water $\times$ acetone:water and ethanol:water $\times$ acetone:water were statistically different $(P=0.0143, P=0.0196$, respectively), but water $\times$ ethanol:water was not statistically different $(P=0.3637)$ (Figure 1a). The Stiasny's Index (SI \%) represents the percentage of polyphenols (condensed tannins) in the extract. Using water, ethanol:water or acetone:water as solvent the SI (\%) was $4.85 \pm 0.68 \%, 4.43 \pm 0.15 \%$ and $14.99 \pm 2.82 \%$ (Figure 1b), respectively. Comparison between water $\times$ acetone: water and ethanol: water $\times$ acetone:water were statistically different $(P=0.0129$ and $P=0.0015$, respectively). The CTE (\%) was $0.74 \pm 0.14 \%, 0.57 \pm 0.39 \%$ and $3.99 \pm 0.51 \%$ for water, ethanol:water and acetone:water (Figure 1c), respectively. The CTE (\%) was statistically different between water $\times$ acetone: water $(P=0.0002)$ and ethanol: water $\times$ acetone: water $(P=0.0005)$. The $\mathrm{CTF}(\%)$ was $0.234 \pm 0.05 \%, 0.173$ $\pm 0.04 \%$ and $1.09 \pm 0.08 \%$ for water, ethanol:water and acetone:water (Figure 1d), respectively. The CTF (\%) was statistically different between 

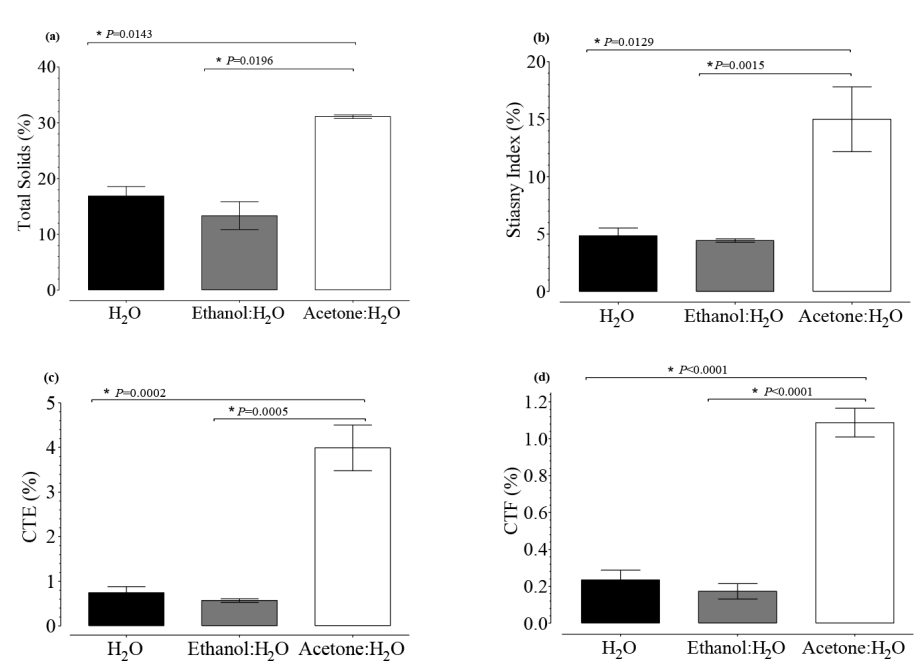

Figure 1: Percentage of total solids [TS (\%)] (a), Stiasny's index [SI (\%)] (b), condensed tannins content in the extract [CTE (\%)] (c) and the condensed tannins content in the unripe fruits [CTF (\%)] (d) for the solvents water, ethanol:water (1:3) and acetone:water (1:3) present in the unripe fruits extract of S. viarum obtained in Soxhlet extraction for $2 \mathrm{hr}$ * statistically significant $(P<0.05)$.

Table 1: Total Polyphenolic concentration, Flavonoid concentration and Antioxidant Activity of unripe fruit extract of $S$. viarum.

\begin{tabular}{cccc}
\hline & $\begin{array}{c}\text { Polyphenolic } \\
\text { concentration }\end{array}$ & $\begin{array}{c}\text { Flavonoid } \\
\text { concentration }\end{array}$ & $\begin{array}{c}\text { Antioxidant } \\
\text { Activity }\end{array}$ \\
\hline & $\begin{array}{c}\text { (mg tannic acid/g } \\
\text { of extract) }\end{array}$ & $\begin{array}{c}\text { (mg quercetin/g } \\
\text { of extract) }\end{array}$ & $\%$ \\
$\begin{array}{c}\text { Solanun viarum } \\
\text { unripe fruit extract }\end{array}$ & $39.33 \pm 4.45$ & $89.36 \pm 11.60$ & $61.12 \pm 12.42$ \\
\hline
\end{tabular}

water $\times$ acetone: water $(P<0.0001)$ and acetone: water $\times$ ethanol:water $(P<0.0001)$.

Table 1 shows the results for total phenols and flavonoid concentration, and antioxidant activity (\%AA) of the unripe fruit extract of S. viarum. The results demonstrated that antioxidant activity was $61.12 \pm 12.42 \%$ compared with the antioxidant activity of ascorbic acid. The antioxidant capacity of the samples was expressed in relation to ascorbic acid, considering its absorbance corresponding to $100 \%$ of antioxidant activity. The flavonoid concentration was $89.36 \pm 11.6 \mathrm{mg}$ of quercetin/g extract. They can act as antioxidant, anti-inflammatory, antiviral, antimicrobial among others. Polyphenol concentration was $39.33 \pm 4.45 \mathrm{mg}$ tannic acid/g extract. The extract contains polyphenolics with appreciable amounts of condensed tannins and flavonoid.

Figure 2 ( $a$ and $b$ ) shows the activities of the extract and positive control at varying concentrations to the hatching success of the $A$. salina cysts. The hatching success of $A$. salina cysts significantly decreased with increasing concentrations of the $S$. viarum extract and the positive control (potassium dichromate) while sea water was the highest hatching potential being observed (Figure 2). The percentage hatching success of cysts incubated with the $S$. viarum extract demonstrated significant differences at varying concentrations (Figure 2 a). The lowest concentration $(1 \mu \mathrm{g} / \mathrm{ml})$ had the highest hatching percentage $(85.3 \pm 2.1 \%)$ and it was not significantly different from the cysts incubated at $10 \mu \mathrm{g} / \mathrm{ml}$ with a hatching success of $83 \pm 10.1 \%$ at $72 \mathrm{~h}$, respectively. With the sea water having a significantly higher hatching success $(93.3 \pm 6.1 \%)$ than the S. viarum extract $(46.3 \pm 8.1 \% ; 26.7 \pm 7.6 \%$; $13.3 \pm 1.5 ; 10.7 \pm 1.2 \%$;
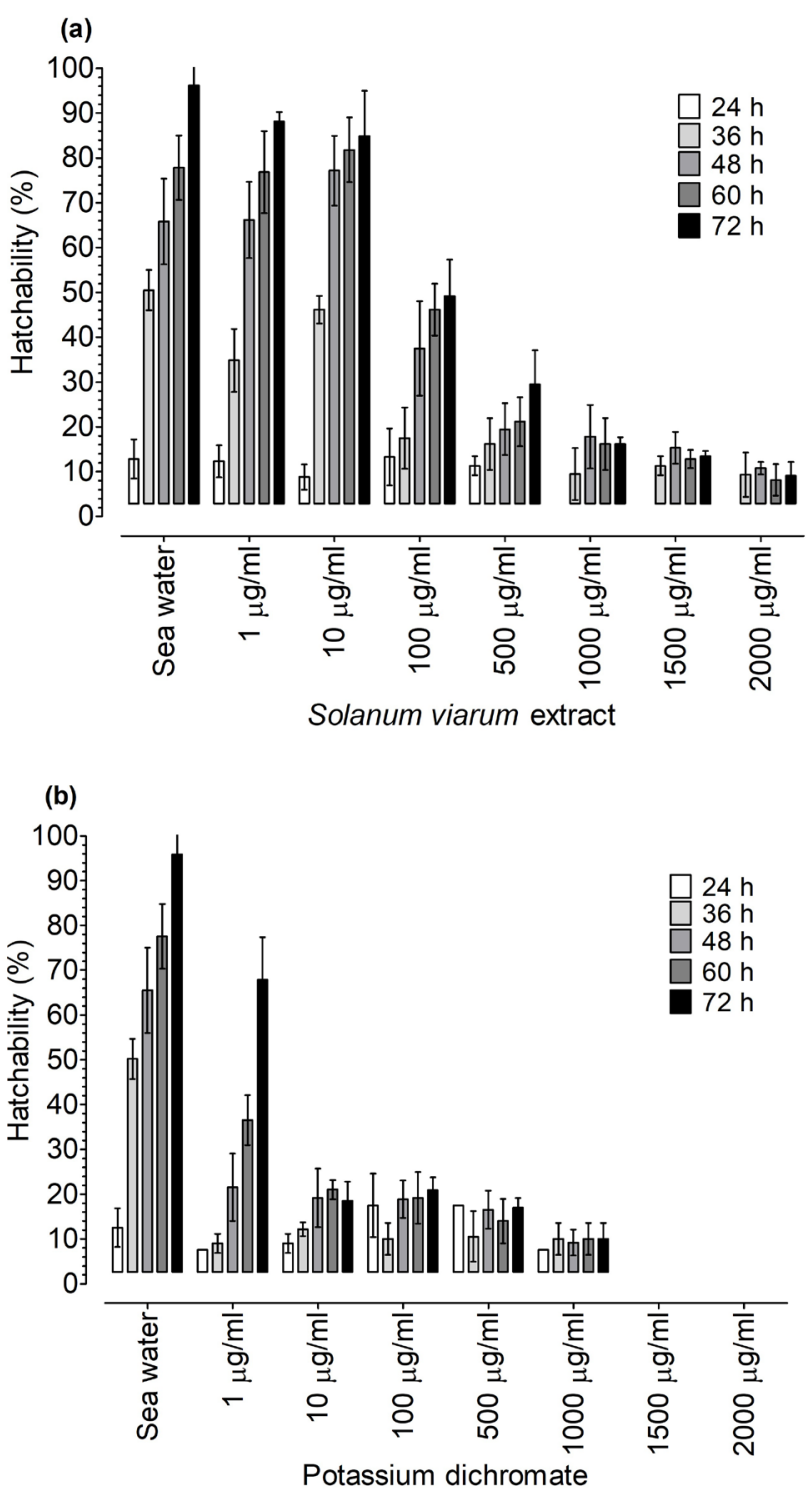

Figure 2: Percentage hatching success of Artemia salina cysts incubated in different concentrations of $S$. viarum extract (a) and potassium dichromate (positive control) (b). The values are means \pm SD of three experiments in triplicate at different concentrations for the extract and controls.

$6.3 \pm 3.1 \%$ at $100,500,1000,1500$ and $2000 \mu \mathrm{g} / \mathrm{ml}$ at $72 \mathrm{~h}$, respectively) $(P<0.05)$, and the positive control (potassium dichromate) presented $65.3 \pm 9.5 \% ; 16 \pm 4.2 \% ; 18.3 \pm 2.9 \% ; 14.5 \pm 2.1 \%$ and $7.5 \pm 3.5 \%$ at 1 , $10,100,500$ and $1000 \mu \mathrm{g} / \mathrm{ml}$ at $72 \mathrm{~h}$, respectively) $(P<0.05)$. There was zero percent hatchability observed from $1500 \mu \mathrm{g} / \mathrm{ml}-2000 \mu \mathrm{g} / \mathrm{ml}$ for potassium dichromate (Figure $2 \mathrm{~b}$ ). The results demonstrated that the positive control (potassium dichromate) hatching success was significantly higher than the extract of $S$. viarum $(P<0.05)$.

The results also demonstrated that after $36 \mathrm{~h}$ of exposure, hatching success of the cysts incubated in sea water was significantly increased by 3.1-fold having a 7.9-fold increase in cyst hatching at the end of $72 \mathrm{hr}$. For cysts incubated in aqueous extract of S. viarum only significantly increased by 1.7 -fold after $36 \mathrm{hr}$ and increased 4.6 -fold after $72 \mathrm{hr}$. For cysts incubated in potassium dichromate, cysts hatching decreased significantly 0.2 -fold after $36 \mathrm{~h}$ and 1 -fold after $48 \mathrm{~h}(P<0.05)$, followed by no hatching of cyst after $60 \mathrm{hr}$. 
Braguini et al:: Tannins Content and Toxicity of S. viarum in Brine Shrimp.

Table 2: The estimated $\mathrm{LC}_{50}$ results for aqueous extract of $S$. viarum and potassium dichromate in Brine Shrimp Lethality Bioassay.

\begin{tabular}{ccccc}
\hline Sample & $\begin{array}{c}\text { Regression } \\
\text { equation }\end{array}$ & $\mathrm{LC}_{50}(\mu \mathrm{g} / \mathrm{ml})$ & $\begin{array}{c}\text { Toxicity } \\
\text { status }\end{array}$ & $\mathrm{R}^{2}$ \\
\hline $\begin{array}{c}\text { S. viarum } \\
\text { aqueous extract }\end{array}$ & $\mathrm{y}=0.7422 \mathrm{x}+$ & 66.01 & Toxic & 0.9756 \\
$\begin{array}{c}3.6495 \\
\text { Potassium }\end{array}$ & $\mathrm{y}=1.208 \mathrm{x}+3.2307$ & 29.15 & Toxic & 0.9536 \\
Dichromate & & & & \\
\hline
\end{tabular}

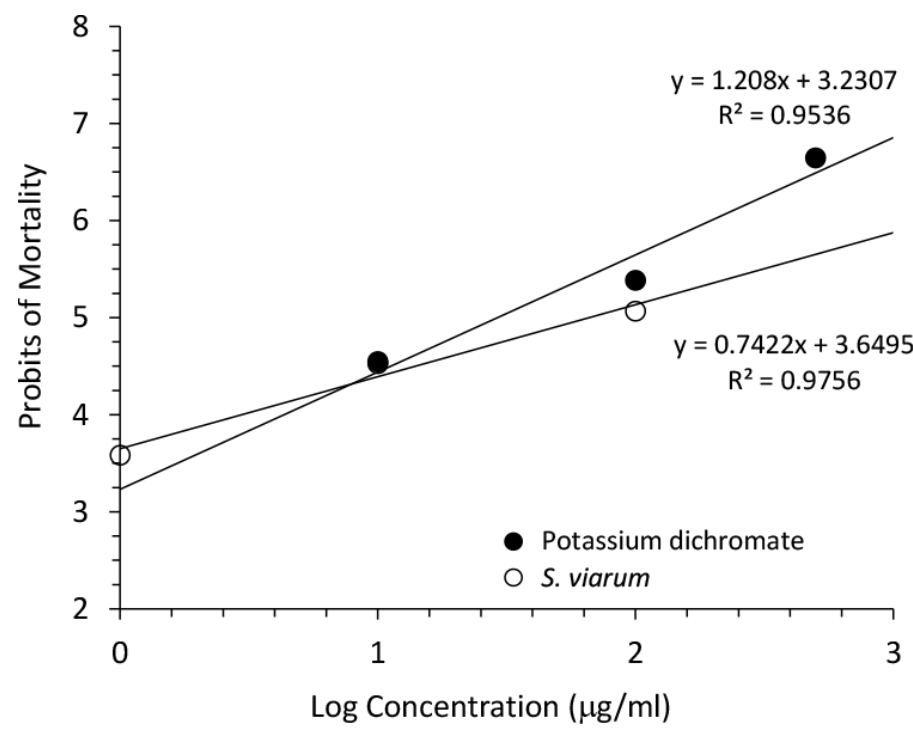

Figure 3: Toxicity effect of potassium dichromate and unripe fruit extract of S. viarum in Brine shrimp nauplii.

Brine shrimp lethality bioassay is a useful test for toxicity screening of plant extracts because it is rapid and also inexpensive. The unripe fruits extract of $S$. viarum have a high $\mathrm{LC}_{50}$ value of $66.01 \mu \mathrm{g} / \mathrm{ml}$ (Figure 3 and Table 2). Potassium dichromate is highly toxic even at very low concentrations. The sea water was observed $0 \%$ mortality through the duration of the experiment. The mortality of nauplii with unripe fruit extract of S. viarum was significantly higher than sea water $(P<0.05)$.

\section{DISCUSSION}

The results demonstrated that the distinct solvents promoted in an unequal manner in the solubility of polyphenolic compounds of extracts, being higher in the acetone: water extract. The aqueous extract presented the lowest value. Ethanol:water (1:3) solvent provided values close to that of aqueous extract, not statistically differing from this solvent $(P>0.05)$. The aqueous extract reveals relative low phenolic contents evaluated by Stiasny's Index. The low value obtained with gravimetric method can be due to the fact that water dissolves preferentially low weight polyphenols. On the other hand, during extraction process in Soxhlet apparatus, the ebullition was violent, because the boiling point of pure water is greater, making the polymerization of the polyphenols possible, and diminishing their reactivity to formaldehyde. The extraction time in Soxhlet was $2 \mathrm{hr}$ and the temperature was the boiling point of each solvent. Ethanol and acetone have boiling points of $78.37^{\circ} \mathrm{C}$ and $56^{\circ} \mathrm{C}$, respectively. The Stiasny's Index (SI) gives an absolute measure for the condensable polyphenols in the extract, but does not represent itself the content of the phenolic material in the extract. The SI by gravimetric method is based on their ability to precipitate polyphenols with a molar excess of formaldehyde during $24 \mathrm{hr}$ in the oven at $100{ }^{\circ} \mathrm{C}$. Additionally, this method is a slow and messy procedure that demands large quantities of extract solution.

On the other hand, we also used a method of polyphenol quantification based in redox chemistry. To quantify the phenolic material content of extract by the method of Folin-ciocalteu, a calibration curve absorbanceconcentration was used. A known standard that could be considered to infer the concentration of the phenolic material, namely the oligomeric molecules of condensed tannins was selected. Tannic acid was used because it can be considered the basic unit for the most common molecules of condensed tannins. This standard provides good linear correlation, and it is frequently used standard for this method. The calibration curve was presented by the equation in materials and methods. We can conclude that the relation absorbance vs. concentration can be acceptably fitted by a linear model for tannic acid as standard. Unripe fruits of $S$. viarum contain a significant quantity of alkaloids, phenols and flavonoids which attribute to the antioxidant capability of this plant. The results suggest that $S$. viarum extract possess a relative free radical scavenging potential and could act and be exploited as a natural source of antioxidants.

The unripe fruit extract of $S$. viarum had significant lower hatching percentage of the cysts above $100 \mu \mathrm{g} / \mathrm{ml}$, and potassium dichromate had significant lower hatching percentage of the cysts above $1 \mu \mathrm{g} / \mathrm{ml}$ (Figure $2 \mathrm{a}$ and $\mathrm{b}$, respectively) compared to the control (sea water). The hatching success significantly decreased with increasing concentrations of the unripe fruits extract, and potassium dichromate elicit 100\% hatching inhibition at $1500-2000 \mu \mathrm{g} / \mathrm{ml}$. Artemia salina has a resistant cyst stage where it can withstand $\mathrm{pH}$ variation (from fresh water to saturated saline), and when dormancy is not interrupted, incubation does not occur. However, $1-10 \mu \mathrm{g} / \mathrm{ml}$ of the unripe fruit extract showed an optimal breaking of dormancy of the cyst and an additional increase in concentration revealed an inhibitory action on the cyst. Evaluation of the hatching success of the cysts in response to exposure time revealed that the extract had significant hatching success after 36-48 hours which is known to be the best hatching time for brine shrimp according to Meyer et al. ${ }^{20}$ However, the cysts incubated in the unripe fruit extract continued to hatch until the end of $72 \mathrm{hr}$ at doses between 1 and $500 \mu \mathrm{g} / \mathrm{ml}$. In incubation with potassium dichromate a low hatching rate of eggs was observed at all doses. The poor hatching success observed in potassium dichromate is due to its high toxicity on cysts of Artemia salina.

Sango et al..$^{23}$ demonstrated that aerial parts extract of Solanum nigrum showed $\mathrm{LC}_{50}$ values of $670 \mu \mathrm{g} / \mathrm{ml}$ and $1840 \mu \mathrm{g} / \mathrm{ml}$ for methanol and water solvents. The unripe fruits of $S$. viarum present higher toxicity in brine shrimp lethality bioassay. There was an increase in mortality with increasing extract concentrations. The lethality rates (probit) were strongly and positively correlated to the extract concentrations, as shown by the correlation coefficients $\left(\mathrm{R}^{2}\right)$. The respective regression line gave $\mathrm{LC}_{50}$ value of $29.15 \mu \mathrm{g} / \mathrm{ml}$ for potassium dichromate (positive control). We use the Clarkson's toxicity criterion ${ }^{24}$ that for the toxicity assessment of plant extracts classifies extracts in the following order: extracts with $\mathrm{LC}_{50}$ above $1000 \mu \mathrm{g} / \mathrm{ml}$ are non-toxic, $\mathrm{LC}_{50}$ of $500-1000 \mu \mathrm{g} / \mathrm{ml}$ are low toxic, extracts with $\mathrm{LC}_{50}$ of $100-500 \mu \mathrm{g} / \mathrm{ml}$ are medium toxic, while extracts with $\mathrm{LC}_{50}$ of $0-100 \mu \mathrm{g} / \mathrm{ml}$ are highly toxic. The unripe fruit extract of $S$. viarum was considered highly toxic by the Clarkson's toxicity criterion $\left(\mathrm{LC}_{50}=66.01 \mu \mathrm{g} / \mathrm{ml}\right)$.

\section{CONCLUSION}

The results of this study indicated that the unripe fruit extract of $S$. viarum reduces cysts hatching and is highly toxic to A. salina suggesting further toxicological studies in vivo and in vitro. It is relevant to know that $S$. viarum rarely involved in human intoxications due to the unique environments in which they are kept. The highest amount of phenolic 
compounds was obtained with the extract of the unripe fruits of S. viarum prepared in acetone:water (1:3). The extract of the unripe fruits of S. viarum contain varying amounts of phytochemicals, considerable antioxidant activity, and the fruits have appreciable amounts of polyphenols. It can be concluded that although the unripe fruits are highly toxic, and when they are available in pastures or roadside, they can be consumed by the cattle. This extract can therefore be used to screen for potential activities against many diseases such as cancer which are triggered by free radicals. Further studies are underway to identify the active compounds responsible for the activities exhibited by the fruits of the plant and to evaluate the anticancer efficacy against cancer cell lines and animal models. Based on the relationship between brine shrimp lethality and plant bioactivity, this work provides subsidies for new biochemical, pharmacological and phytochemical research.

\section{ACKNOWLEDGEMENT}

The authors gratefully acknowledge to Universidade Estadual do Centro Oeste by facilities and equipment of Biochemistry Lab.

\section{CONFLICT OF INTEREST}

No potential conflict of interest was reported by the authors.

\section{ABBREVIATIONS}

LC $_{50}$ : Lethal Concentration 50; h: hour; SI: Stiasny's Index; TS: Total Solids; CTE: Condensed Tannins in the Extract; CTF: Condensed Tannins in the Unripe Fruits.

\section{REFERENCES}

1. Vendruscolo GS, Rates SMK, Mentz LA. Dados químicos e farmacológicos sobre as plantas utilizadas como medicinais pela comunidade do bairro Ponta Grossa, Porto Alegre, Rio Grande do Sul. Rev Bras Farmacogn. 2005;15(4):361-72.

2. Lorenzi H. Plantas daninhas do Brasil: terrestres, aquáticas, parasitas e tóxicas. 3rd ed. Nova Odessa: Plantarum. 2000.

3. Akanda RU, Mullahey JJ, Shilling DG. Environmental factors affecting germination of tropical soda apple (Solanum viarum). Weed Sci. 1996;44(3):570-4.

4. Milner SE, Brunton NP, Jones PW, O Brien NM, Collins SG, Maguire AR. Bioactivities of glycoalkaloids and their aglycones from solanum species. J Agricult Food Chem. 2011;59(8):3454-84.

5. Mentz LA, Lutzemberger L, Schenkel EP. Da Flora Medicinal do Rio Grannde do Sul: Notas sobre a Obra de D'ávila (1910). Cad Farmácia. 1997;5(13):25-48.

6. Pawar P, Borse T, Pinjari R, Maheshwari V. A Simple Technique for Rapid Quantitative Determination of Solasodine from Cultured Hairy Roots of Solanum surattense. J Herb Med Toxicol. 2008;2(1):7-10.
7. Patel K, Singh RB, Patel DK. Medicinal significance, pharmacological activities, and analytical aspects of solasodine: A concise report of current scientific literature. J Acute Dis. 2013;2(2):92-8.

8. Grandi T, Trindade J, Pinto M, Ferreira L, Catella A. Plantas Medicinais de Minas Gerais, Brasil. Acta Bot Bras. 1989;3(2):185-224.

9. Aryaa A, Viswanathswamy AH. Effect of Solanum nigrum Linn on Acute and Sub-Acute Models of Inflammation. 2017;9(4):566-70.

10. Carputo D, Savarese S, Andolfi A, Aversano R, Cimmino A, Frusciante L, et al. Glycoalkaloid profile in potato haploids derived from Solanum tuberosum S. bulbocastanum somatic hybrids. Chem Biodivers. 2010;7(8):1885-92.

11. Al Sinani SS, Eltayeb EA, Kamal YT, Khan MS, Ahmad S. Variations in the cytotoxic glycoalkaloids solamargine and solasonine in different parts of the Solanum incanum plant during its growth and development in Oman. J Taibah Univ Sci. 2016;10(6):813-22.

12. Cipollini ML, Levey DJ. Why are some fruits toxic? Glycoalkaloids in Solanum and fruit choice by vertebrates. Ecology. 1997;78(3):782-98.

13. Zitnak A. Steroids and capsaicinoids of solanaceous food plants. In: Childers NF, Russo GM, editors. Nightshades and health. New Jersey: Somerset Press. 1979;41-91.

14. Van Gelder W. Chemistry, toxicology, and occurrence of steroidal glycoalkaloids: potential contaminants of the potato (Solanum tuberosum L.). In: Rizk AFM editor. Poisonous plant contamination of edible plants. Boca Raton: CRC Press. 1990;117-56.

15. Guangcheng Z, Yunlu L, Yazaki Y. Extractives yields, stiasny values and polyflavanoid contents in barks from six acacia species in Australia. Aust For 1991;54(3):154-6.

16. Singleton $\mathrm{VL}$, Orthofer $\mathrm{R}$, Lamuela-Raventos RM. Analisys of total phenols and other oxidation sobstrates and antioxidants by means of Folin Ciocalteau reagent. Methods Enzymol. 1999;299:152-78.

17. Zhishen J, Mengcheng T, Jianming W. The determination of flavonoid contents in mulberry and their scavenging effects on superoxide radicals. Food Chem. 1999;64(4):555-9.

18. Prieto P, Pineda M, Aguilar M. Spectrophotometric Quantitation of Antioxidant Capacity through the Formation of a Phosphomolybdenum Complex: Specific Application to the Determination of Vitamin E. Anal Biochem. 1999;269(2):337-41.

19. Otang WM, Grierson DS, Ndip RN. Assessment of potential toxicity of three South African medicinal plants using the brine shrimp (Artemia salina) assay. Afr J Pharm Pharmacol. 2013:7(20):1272-9.

20. Meyer B, Ferrigni NR, Putnam JE, Jacobsen LB, Nichols DE, McLaughlin JL. Brine Shrimp: A Convinient General Bioassay for Active Plant Consyituents. J Med Plant Res. 1982;45(5):31-4.

21. McLaughlin JL, Rogers LL, Anderson JE. The Use of Biological Assays to Evaluate Botanicals. Drug Inf J. 1998;32(2):513-24.

22. Finney DJ. Probit Analysis. J Pharm Sci. 1971;60(9):1432.

23. Sango C, Marufu. L, Zimudzi. C. Phytochemical, Anti-nutrients and Toxicity Evaluation of Cleome gynandra and Solanum nigrum: Common Indigenous Vegetables in Zimbabwe. Br Biotechnol J. 2016;13(3):1-11.

24. Clarkson C, Maharaj VJ, Crouch NR, Grace OM, Pillay P, Matsabisa MG, et al. In vitro antiplasmodial activity of medicinal plants native to or naturalised in South Africa. J Ethnopharmacol. 2004;92(2-3):177-91.

Article History: Submission Date : 24-12-2017 ; Revised Date : 13-02-2018; Acceptance Date : 23-02-2018.

Cite this article: Braguini WL, Pires NV, Bianchin BA. Phytochemical Analysis, Antioxidant Properties and Brine Shrimp Lethality of Unripe Fruits of Solanum viarum. J Young Pharm. 2018;10(2):159-63. 